Research Articles

\title{
Roles of Macroeconomic Variables on Agricultural Diversification in Nigeria
}

\author{
Sunday B. Akpan, Samuel J. Udoka and Inimfon V. Patrick \\ Department of Agricultural Economics and Extension, Akwa Ibom State University, Nigeria
}

\author{
Article history \\ Received: 9-3-2015 \\ Revised: 21-5-2015 \\ Accepted: 4-7-2015
}

Corresponding Author: Sunday Brownson Akpan Department of Agricultural Economics and Extension, Faculty of Agriculture, Akwa Ibom State University, Nigeria

Email: brownsonakpan10@gmail.com

\begin{abstract}
The study examined the trend in agricultural diversification index from 1960 to 2014 in Nigeria. It also determined the influence of some macroeconomic variables on the estimated index. Augmented Dickey-FullerGLS unit root test showed that all series were integrated of order one. The long-run and short-run elasticity of the agricultural diversification index with respect to the specified macro-economic variables were determined using the techniques of co-integration and error correction models. The trend analysis revealed that, the country has witnessed appreciable level of agricultural diversification with $0.3 \%, 0.5 \%$ and $2.3 \%$ annual exponential growth rate in entropy diversification index, Herfindhal diversification index and Ogive diversification index respectively. The estimation of the error correction model supported the long run stability of agricultural diversification index in Nigeria. The empirical results revealed that, in the long run inflation, viable manufacturing sector, credit to agricultural sector, external reserves, per capita income, unemployment and energy consumption are positive drivers of agricultural diversification; whereas, crude oil prices, lending capacity of commercial Bank, foreign direct investment in agricultural sector and non-oil import are long run negative drivers of agricultural diversification in Nigeria. However, in the short run, inflation, external reserves and non-oil imports stimulated agricultural diversification; while energy consumption and manufacturing capability retard agricultural diversification in the country. A ten-year forecast was made on the estimated diversification indices and the result showed a progressive growth. The empirical results were further substantiated by the variance decomposition and impulse response analysis of the dependent variable with respect to changes in the explanatory variables. Results obtained were in line with the previous results. It is recommended that, the Nigeria government should re-aligned its macroeconomic policies to achieve stability in inflation rate, external reserves, industrial production, electricity consumption, agricultural credit institution if sustainable agricultural diversification is to be achieved in the long run.
\end{abstract}

Keywords: Agriculture, Diversification, Macroeconomics, Nigeria, Economy

\section{Introduction}

Literature has provided few evidences on the relationship between agricultural diversification and macroeconomic variables in Nigeria. Agricultural diversification occurs if government channeled more of her resources to other sectors of economy and at the same time sustains positive growth in agricultural sector. This process takes place by reducing the prolonged dominancy of one sector in the country's GDP. The country quest for sustainable diversification from agrarian society to a more liberal and competitive economy is vital to the long-term economic growth. In developed economies, agricultural sector constitutes a small share of their GDP'scompared to the manufacturing, whole sale and retail trades as well as the service sectors. When the economy is heavily depended on income generated from a narrowed based source, sustaining long-term economic growth and development became a serious challenge due to volatility in prices and 
allocative inefficiencies. To remedy this situation, governments need to develop and implement effective sectorial diversification strategies.

The role of agricultural sector as one of the main drivers of non-oil sector growth in Nigeria is obvious. For instance, the sector contributed about 53.95\% share of non-oil contribution to GDP from 2010 to 2014 (CBN, 2015 and see Table 1). Despite the dominant share of agricultural sector in the non-oil sector's contribution to the GDP, the country has made several attempts to diversify the economy by boosting the contributions of other non-oil sectors in the GDP. Apart from building institutional frameworks, fiscal and monetary policies have been enunciated and implemented to boost services, industrial production, building and construction sectors as well as the whole sale and retail trades sectors in the country. These efforts of the federal government have yielded positive impact through progressive increase in the share of building and construction as well as whole sale and retail business in the total GDP from 2000 to 2014 (see Table 1).

Many proponents of economy diversification held that, economic diversification is one of the prerequisites for economic growth sustainability (Odife, 2004; Olaleye et al., 2013). It is generally accepted that, economic diversification promotes economy expansion, generate employment and ease resources intensification. However, lack of diversification may increase exposure to adverse external shocks and macroeconomic instability (Papageorgiou and Nikolas, 2013). The need to diversify the country's economy is far important now than ever. Since the country depends so much on sale of crude oil and agricultural production, the current global declined in oil prices and the mounting youth unemployment as well as increase in rural and urban poverty call for the overwhelming need to diversify the country's economy in order to generate sufficient employment opportunities. The increasing price volatility of agricultural commodities in addition to unhealthy competition existing in some agricultural commodity markets in the country also support this clarion call for sustainable government diversification from agricultural sector.

It is believed that, such diversification attempt will help to develop other sectors of the economy, create demand for agricultural sector, improve value addition in agriculture, increase income of farmers, encourage specialization in agricultural sector and triggered sustainable long term growth and development in the country. This kind of diversification basically focused on attempts to increase revenue from manufacturing, solid minerals mining, building and construction, whole sales and retail trades and a wide range of services while still sustaining positive growth in agricultural sector. To achieve this objective, government must have to re- allocate resources through investment in human capital, infrastructures and utilities among others. In theory, agricultural sector has received a fair share of these investments in form of subsidies, proliferation of agricultural programmes and institutions among others. Despite these incentives and robust policy framework designed to enhance the sector's productivity, it is on record that, Nigeria is a net importer of grains and other agricultural commodities in the world. Hence, as a policy shift, agricultural diversification becomes one of the best alternative options.

Since agricultural sector is an important component of the economy system, there is also need to identify the relationship between the sector's activities and other components of economy system. Macroeconomic variables are dynamic elements in the economy system that affects all sectors' activities. Hence, understanding the relationship between the agricultural diversification drive and macroeconomic variables in the economy will fine-tune the path for sound policies on economic diversification in the country. Based on this premised, the paper was basically designed to investigate the level of agricultural diversification by using stream of incomes generated by various sectors in the economy. In addition, it determined the relationship between the measured of agricultural diversification and some macroeconomic fundamentals in the economy.

\section{Reviewed of Related Literature}

Few literature have delved into the relationship between macroeconomic variables and economic diversification. For instance, Imbs and Wacziarg (2003) documented that higher income per capita is associated first with diversification and then with re-concentration, in production and employment. Feenstra et al. (1998) examined the linkage between changes in export diversification and the growth in Total Factor Productivity (TFP) in South Korea and Taiwan in the period 1975-1991. The empirical evidence supported a positive and significant relationship between the two variables in both countries. Piñeres and Ferrantino (1997) examined the influence of export diversification on economic growth in the periods 1962-1991 in Chile. Their result confirmed positive significant linked between the domestic economic performance and diversification. Using different measures of export diversification on a cross country sample of 91 countries and covering the period 1961-1988, Fahim Al-Marhubi (1998) presents empirical evidence that export diversification promotes economic growth.

However, this few related literature do not relate diversification with broad base macroeconomic variables. Also, agricultural diversification has not enjoyed good patronage from researchers especially in developing countries like Nigeria. 
Table 1. Share of Components of GDP in total GDP and Average value and Percentages of some Macroeconomic Variables in Nigeria

\begin{tabular}{|c|c|c|c|c|c|c|}
\hline Components of GDP & 1960-1969 & 1970-1979 & 1980-1989 & 1990-1999 & 2000-2009 & $2010-2014$ \\
\hline Agriculture (\%) & 48.79 & 20.17 & 31.53 & 26.03 & 30.34 & 32.60 \\
\hline Industry (\%) & 17.28 & 40.65 & 43.20 & 51.49 & 44.71 & 39.57 \\
\hline Building/Cons. (\%) & 5.11 & 7.40 & 1.62 & 0.67 & 1.16 & 1.32 \\
\hline Whole sale/R. (\%) & 12.69 & 19.38 & 13.40 & 11.51 & 13.68 & 15.43 \\
\hline Services $(\%)$ & 16.13 & 12.40 & 10.25 & 10.30 & 10.11 & 11.08 \\
\hline TOTAL & 100.00 & 100.00 & 100.00 & 100.00 & 100.00 & 100.00 \\
\hline \multicolumn{7}{|c|}{$\begin{array}{l}\text { Average value and Percentages } \\
\text { of some Macroeconomic Variables in Nigeria }\end{array}$} \\
\hline Crude oil price $(\mathrm{N})$ & 0.86 & 7.5 & 178.92 & 2818.10 & 1163.06 & 15696.94 \\
\hline Inflation (\%) & 13.80 & 9.90 & 7.50 & 6.94 & 13.70 & 10.65 \\
\hline Lending rate. $(\%)$ & 7.00 & 19.41 & 25.30 & 21.30 & 17.60 & 17.02 \\
\hline
\end{tabular}

Source: Computed by authors, data obtained from CBN and NBS

This is one aspect this study explored in a bit to expand the policy framework on diversification in developing countries. Again, empirical literature on agricultural diversification in the Nigeria's economy is absent; this is dangerous especially now that the country is trying to diversify her source of revenue following increase price volatility in international crude oil market.

\section{Theoretical Framework (Economic Development Theory)}

Following economic development theories, economic diversification is driven by concurrent changes in production, consumption, labour supply, level of investment (capital) and trade patterns as well as government policies or intention (Petit and Barghouti, 1992; Rodriguez-Clare, 2005). Alternatively, sectoral diversification depends not only on its own efforts and abilities and on general economic conditions (for example, the macroeconomic environment and the legal system), but also on the actions of other firms, infrastructure, regulation and other public goods" (Rodriguez-Clare, 2005). Following these assertions, agricultural diversification could be expressed as a function of macroeconomic variables in any market driven economy.

\section{Measurement of Agricultural Diversification Index}

Several methods have been used to measure diversification in the literature. This study used five popular methods to estimate index of agricultural diversification in the Nigeria's economy. The index was generated based on the structure of the Nigeria's GDP. There are five major categories of income sources in the country's GDP structure. These are Agricultural source; Industry source; Building and construction source, whole sale and retail trade sources and services source. The summation of income from these five sources is equivalent to the annual GDP of Nigeria. Hence, agricultural diversification index was estimated based on the contribution of agricultural sector relative to other sectors in the total GDP of Nigeria. Hence, each diversification method estimated is explained explicitly below.

\section{The Herfindahl Diversification Index}

In this study, Harfindhal Index (HI) was defined as the square of the proportion of agricultural income in the GDP. This was computed on annual basis; hence the index became the summation of the square of the proportion of agricultural income in the GDP within a year. It is described as follow:

$$
H I=\sum_{i=1}^{N} P_{i}^{2}
$$

where, $\mathrm{HI}$ is Herfindhal Concentration Index, $\mathrm{N}=$ total number of categorized income sources in the economy and $\mathrm{P}_{\mathrm{i}}$ is the proportion of agricultural income $\left(\mathrm{Y}_{\mathrm{k}}\right)$ in the total income or GDP $\left(\mathrm{Y}_{\mathrm{N}}\right)$. Hence, $\mathrm{P}_{\mathrm{i}}=\mathrm{Y}_{\mathrm{k}} / \mathrm{Y}_{\mathrm{N}}$. Herfindahl index described in Equation 1 is also known as concentration index. The value ranges from zero to one. It measures the degree of concentration of a particular income source in the total income of a given economy. Herfindhal concentration index of zero and unity imply complete diversification and specialization respectively. The Herfindhal concentration index was transformed to measure diversification index in agricultural sector as thus Equation 2:

$$
\text { HD1 = 1- (HI) }
$$

The Herfindhal Diversification Index (HDI) has direct relationship with diversification; it takes the value of zero in case of complete specialization or concentration while a unity index indicates perfect diversification.

\section{The Ogive Index of Diversification}

This index is also a measure of concentration. Following McLaughlin (1930) and Tress (1938), the Ogive Index (OI) is constructed as follows: (Note it was computed on annual basis) Equation 3: 


$$
O 1==\sum_{i=1}^{N} \frac{\left\{P_{i}-\left(\frac{1}{N}\right)\right\}^{2}}{\left(\frac{1}{N}\right)}
$$

Note, variables are as defined previously. When the OI index approaches 0 , it means the economy is highly diversified; while a larger index indicates less diversification or more specialization. For easy interpretation, the $\mathrm{OI}$ is re-computed to measure diversification as thus Equation 4:

$$
O D I=1-(O . I)
$$

In this form, Ogive Diversification Index (ODI) varies directly with diversification and inversely with specialization.

\section{The Entropy Index}

This index has a positive relationship with diversification and is inversely related to specialization. It approaches zero when the economy is fully specialized and takes a maximum value when there is perfect diversification. At perfect specialization, all income in the GDP is concentrated in just one category or sector resulting in a zero value for the Entropyindex. On the other hand, if income is distributed equally among the "N" sectors in the GDP, the Entropyindex would reach its maximum value, indicating perfect diversity. In the case of "N" sector, the range for the entropy index is zeroto $\operatorname{Ln}(\mathrm{N})$. Hence, the upper limit of this Index depends on the base of logarithm and the number of income sources considered (Shiyani and Pandya, 1998). Following Smith and Gibson (1988), the Entropy index of diversity can be defined as follows Equation 5:

$$
E I=-\sum_{i=1}^{N} P_{i} \operatorname{In} P_{i} \text { or } \sum_{i=1}^{N} P_{i} \operatorname{In}\left(\frac{1}{P_{i}}\right)
$$

The index has the limitation of not giving standard scale in assessing the degree of diversification. The Entropy index defines diversity in terms of equality of distribution of income across all sources in the GDP. It was computed on annual basis.

\section{Modified Entropy Index}

The modified Entropy index is used to overcome the limitations of the Entropy index by using a variable base of logarithm instead of a fixed base of logarithm. The index (MEI) lies between zero (complete specializations) and one (perfect diversification). It is computed as an annual index as follows Equation 6:

$$
M E I=-\sum_{i=1}^{N} P_{i} \log _{N} P_{i} \text { or } \frac{E I}{\log N}
$$

This index has a lower limit equal to zero when there is complete specialization or concentration and it assumes an upper limit of one in the case of perfect diversification.

\section{Composite Entropy Index}

The value of Composite Entropy Index increases with decrease in concentration (specialization) and rise with increase proportion of $i_{\text {th }}$ income source in the total income activities (diversification). The value of the index ranges from zero to unity. Annual computation is as follows Equation 7:

$$
C E I=-\left(\sum_{i=1}^{N} P_{i} \log _{N} P_{i}\right)\left(1-\left(\frac{1}{N}\right)\right) \text { or } M E I\left(1-\left(\frac{1}{N}\right)\right)
$$

The five methods were used to estimate agricultural diversification indexes. However, the result revealed that EDI, MEI and CEI were similar.

\section{Research Methodology}

Study Area: The study was conducted in Nigeria; the country is situated on the Gulf of Guinea in the sub Saharan Africa. Nigeria lies between $4^{0}$ and $14^{0}$ North of the Equator and between longitude $3^{\circ}$ and $15^{\circ}$ East of the Greenwich. The country has a total land area of about $923,769 \mathrm{~km}^{2}$ (or about 98.3 million hectares) with $853 \mathrm{~km}$ of coastline along the northern edge of the Gulf of Guinea and a population of over 140 million people (NPC, 2015). Nigeria is bounded by the Republics of Benin in the west, Chad and Cameroon in the east and Niger to the north.

Data source: Secondary data were used for the study. These data were sourced from the statistical bulletins of the Central Bank of Nigeria (CBN).The data were annual income from the five major component areas of the Nigeria GDP. Data covered the period from 1960 to 2014.

\section{Analytical Techniques}

Series of statistical and econometric techniques were employed to analyze the objectives of the study. Explicitly they are explained as thus:

The trend Analysis of Agricultural Diversification in Nigeria (1960-2014)

The study investigated the nature of movement and growth rate in the agricultural diversification index in Nigeria. An exponential trend Equation 8 was specified as thus:

$$
\log _{e} A D I_{t}=b_{0}+b_{1} T+U_{t}
$$

where, ' $\mathrm{T}$ ' is the time expressed in year; ADI's are various indices of agricultural diversification in Nigeria. The exponential growth rate is given as in Equation 9: 


$$
(r)=\left(e^{b 1}-1\right) * 100
$$

To ascertain whether the growth rate in agricultural diversification index estimated increases at accelerated or decelerated rate over increased period of time, the quadratic exponential trend Equation 10 was specified as thus:

$\log _{e} P_{t}=b_{o}+b_{1} t_{1}+b_{2} t_{2}^{2}+u_{t}$

If $b_{2}>0$; the index investigated had accelerated growth rate: when $b_{2}<0$; the growth rate is not significant.

The Long Run Relationship between Agricultural Diversification Index and Macroeconomic Variables in Nigeria

To determine the long run relationship between Agricultural Diversification Index and selected macroeconomic variables in Nigeria, a time dependent regression model was specified at the level of variables. The model is specified as follows:

$$
\begin{aligned}
& \operatorname{LnADI}_{t}=\gamma_{0}+\gamma_{1} \sum_{i=1}^{n} \operatorname{LnCOP}_{t} \\
& +\gamma_{2} \sum_{i=1}^{n} \operatorname{LnPCG}_{t}+\gamma_{3} \sum_{i=1}^{n} \operatorname{LnINF}_{t} \\
& +\gamma_{4} \sum_{i=1}^{n} \operatorname{LnFDI}_{t}+\gamma_{5} \sum_{i=1}^{n} \operatorname{LnUEM}_{t} \\
& +\gamma_{6} \sum_{i=1}^{n} \operatorname{LnIEC}_{t}+\gamma_{7} \sum_{i=1}^{n} \operatorname{LnIMP}_{t}+\gamma_{8} \sum_{i=1}^{n} \operatorname{LnLEN}_{t}+ \\
& +\gamma_{9} \sum_{i=1}^{n} \operatorname{LnCAS}_{t}+\gamma_{10} \sum_{i=1}^{n} \operatorname{LnEXD}_{t} \\
& +\gamma_{11} \sum_{i=1}^{n} \operatorname{LnEXR}_{t}+\gamma_{12} \sum_{i=1}^{n} \operatorname{LnNOI}_{t}+U_{t}
\end{aligned}
$$

Where:

$$
\begin{aligned}
\mathrm{ADI}_{\mathrm{t}}= & \text { Various measures of agricultural } \\
& \text { diversification Index (HDI, ODI and EDI) } \\
\mathrm{COP}_{\mathrm{t}}= & \text { Annual crude oil prices (N) } \\
\mathrm{PCG}_{\mathrm{t}}= & \text { Annual per capita GDP (N/Person) } \\
\mathrm{INF}_{\mathrm{t}}= & \text { Annual Inflation rate }(\%) \\
\mathrm{FDI}_{\mathrm{t}}= & \text { Foreign direct investment in Agricultural } \\
& \text { sector }(\mathrm{Nm}) \\
\mathrm{UEM}_{\mathrm{t}}= & \text { Unemployment rate in Nigeria }(\%) \\
\mathrm{IEC}_{\mathrm{t}}= & \text { Index of energy consumption }(1985=100)(\%) \\
\mathrm{IMP}_{\mathrm{t}}= & \text { annualindex of manufacturing production } \\
& (1990=100)(\%) \\
\mathrm{LEN}_{\mathrm{t}}= & \text { Lending rate of commercial Bank }(\%) \\
\mathrm{CASt}= & \text { Credit to agricultural sector/GDP } \\
\mathrm{EXD}_{\mathrm{t}}= & \text { External debt/GDP } \\
\mathrm{EXR}_{\mathrm{t}}= & \text { External reserve/GDP } \\
\mathrm{NOI}_{\mathrm{t}}= & \text { Non-oil import/GDP } \\
\mathrm{U}_{\mathrm{t}}= & \text { Stochastic error term and } U_{t} \sim \mathrm{IID}\left(0, \delta_{\mathrm{U}}^{2}\right)
\end{aligned}
$$

To validate the existence of the long run stable relationship between the agricultural diversification index and some macroeconomic variables in Nigeria, the study applied the Engle and Granger two-step technique and Johansen co-integration test. Following the Granger Representation Theorem, the Error Correction Model (ECM) for the co-integrating series in the study was specified. The general specification of the Error Correction Model for the agricultural diversification index equation in Nigeria is shown in Equation 12:

$$
\begin{aligned}
\Delta \operatorname{LnADI}_{t} & =\beta_{0}+\gamma_{1} \sum_{i=1}^{n} \Delta L n A D I_{t-1} \\
& +\beta_{2} \sum_{i=1}^{n} \Delta \operatorname{Ln} X_{t-1}+\beta_{3} E C M_{t-1}+U_{t}
\end{aligned}
$$

The variables are as defined previously in Equation 11; and coefficients $\left(\beta_{3}\right)$ of the $\mathrm{ECM}_{t}(-$ $\left.1<\beta_{3}<0\right)$ measures the deviation from the long-run equilibrium in period $(\mathrm{t}-1)$.

\section{Augmented Dickey-Fuller (ADF)-GLS Unit Root Test}

Time series can be stationary or non-stationary at first or higher difference. Stationary series implies that, data have constant mean, variance and minimal incidence of autocorrelation as well of time invariant (Brooks, 2008). On the other hand, a non-stationary series is time variant meaning it possess time varying mean, variance or both. The analysis of non- stationary series using the Ordinary Least Squares (OLS) estimation method will likely yield spurious or nonsense estimates (Gujarati, 2003).

Hence, stationary of time series is needed to avoid the incidence of spurious regression. It is therefore necessary to convert non- stationary series to stationary status in order to obtain reliable regression estimates. In estimating an Error Correction Model, this study applies the Augmented Dickey-Fuller (ADF) - GLS test to examine the stationary characteristics of the series. As suggested by Dickey and Fuller (1981), Equation (13) is used to test the stationary of specified variables:

$\Delta y_{t}=\mu_{t}+\alpha_{2} y_{t-1}+\sum_{i=1}^{k} \beta_{i} \Delta y_{t-i}+\varepsilon_{t}$

where, ' $y$ ' represents the variables to be tested, $\Delta$ represents the first difference operator; $t$ is the time drift; $k$ represents the number of lags used and $\varepsilon$ is the error term, which is assumed to be normally and identically distributed with constant means and variance;' $\alpha$ and $\delta$ are the model bounds. It is a one-sided test whose null hypothesis is $\alpha_{2}=0$ versus the alternative $\alpha_{2}<0$. Following the work of Elliott et al. (1996), ADF-GLS unit root involves estimating the standard ADF test equation 
after substituting the Generalized Least Squares detrended $y_{t}^{d}$ for the original $\mathrm{y}_{\mathrm{t}}$ as shown in Equation 14. The test variant offers greater power than the regular ADF test:

$$
\Delta y_{t}^{d}=\alpha_{2} y_{t}^{d}+\sum_{i=1}^{k} \beta y_{t-1}^{d}+V_{t}
$$

\section{Results and Discussion}

\section{Descriptive Statistics}

The descriptive statistics of variables used in the study is shown in Table 2 . The result revealed an average index of about 0.844 for Herfindhal Diversification index, 0.778 for Ogive diversification index, 0.352 for entropy diversification index, 0.219 for modified entropy index and 0.175 for composite entropy index. The coefficient of variability of 0.059 (or about $5.9 \%$ variability) was similar in entropy index, modified entropy index and composite entropy index. This result revealed that, the degree of variations in EDI, MED and CEI are similar. However, coefficient of variability in HDI was 0.113 and 0.329 in ODI. This means that, about $11.30 \%$ and $32.90 \%$ variations occur in HDI and ODI respectively within the period under consideration. The specified macroeconomic variables also showed varied degrees of variability as well as Skewness. The descriptive analysis was further enhanced by the trend analysis using equation and graphical representation.

\section{Unit Root Test of Variables used in the Analysis}

To ascertain the stationary of variables used in the study, the standard Augmented Dickey-Fuller GLS test for unit root was performed. Test statistic for each variable in level and first difference involving both trend and without trend ADF-GLS equations are presented in Table 3. The test was done at the level of the variables to improve the degree of freedom of data set. The ADFGLS test result reveals that at level, all specified variables were non stationary, but were stationary at first difference. The critical value was kept at $1 \%$ significant level to ensure the best result. The result of the ADF-GLS unit root test implies that, the analysis of the specified variables at their levels could result in spurious regression estimates. This indicates that, the variables should be tested for the presence of co-integration and Error Correction mechanism (Johansen, 1988; Johansen and Juselius, 1990).

\section{Result of Trend Analysis of Agricultural Diversification Index in Nigeria}

Estimates of the exponential trend equation for each of the index are presented in Table 4 . The result revealed that, agricultural diversification indexes have positive significant associations with time in Nigeria. This implies that, on average the agricultural diversification index showed marginal direct relationship with time. However, HDI and ODI showed average exponential growth rates of about $0.5 \%$ and $2.30 \%$ per annum respectively. Similarly, EDI, MEI and CDI grew at an average rate of $0.30 \%$ per annum. These results connote that, agricultural diversification had not witnessed significant and sustainable boost in Nigeria. The result shows that, the country is still rooted deep in agricultural activities compared to activities in other sectors (manufacturing, building and construction, whole sale and retailed trade and service) of the economy. Coefficient of the square time in the quadratic trend equation for each index indicates that, there is a significant negative relationship between agricultural diversification index and square of time in Nigeria. The result showed marginal declined in these indexes over increase time period. Declined in Agricultural diversification over time implies increase in agricultural intensification or concentration. This result exposed the strength of agricultural sector in the country's GDP compared to the continuous weakness of other non-oil sectors (manufacturing, building and construction, whole sale and retailed trade and service) in the Nigeria's economy.

It means that, past governments in the country have pivoted their efforts on agricultural development which contributed to decline in productivity of other non-oil sectors in the economy. This suppresses agricultural diversification in the long run but rather promotes agricultural intensification. Alternatively, it could be that, the various fiscal and monetary policies as well as incentives implemented by various government regimes to diversify the economy were not effective, hence the continuous dominant of agricultural sector among the non-oil sectors in the GDP.

To further substantiate the trend behaviour of agricultural diversification index in Nigeria, Fig. 1 shows the linear trend graphs of HDI, ODI, EDI, MED and CDI from 1960 to 2014. It is observed that, EDI, MED and CDI exhibited the same pattern of fluctuations during the period. It is concluded that, theses agricultural indexes are similar and is therefore discussed as one. The HDI and ODI showed upward trend during early 1960 to 1980. This upward trend is largely attributed to increase in crude oil earnings of this period. Also, the import substitution industrialization policy of this era provided effective protection to the local manufacturing industries, through such measures as quantitative restrictions and high import duties on finished goods (Ogun, 1987). The exchange rate policy became protectionist and by 1972 the domestic currency was overvalued. Following the implementation of these policies, the rate of growth of import fell and competition between foreign and domestic firms manufactures reduced; consequently domestic industrial activities witnessed an impressive growth. During early 1960s, agricultural diversification was minimal because the country depended on agricultural exports for her revenue earnings. 
Sunday B. Akpan et al. / American Journal of Economics and Business Administration 2015, 7 (2): 77.93 DOI: 10.3844/ajebasp.2015.77.93

Table 2. Summary Statistics, using the observations 1960-2014

\begin{tabular}{|c|c|c|c|c|c|c|c|c|}
\hline Variable & Mean & Median & Min. & Max. & Std. Dev. & C.V. & Skewness & Ex. kurtosis \\
\hline HDI & 0.844 & 0.883 & 0.597 & 0.959 & 0.0950 & 0.113 & -1.187 & 0.413 \\
\hline ODI & 0.778 & 0.899 & 0.055 & 0.999 & 0.256 & 0.329 & -1.513 & 1.141 \\
\hline EDI & 0.352 & 0.363 & 0.289 & 0.368 & 0.021 & 0.059 & -1.531 & 1.430 \\
\hline MED & 0.219 & 0.226 & 0.179 & 0.229 & 0.013 & 0.059 & -1.531 & 1.430 \\
\hline CEI & 0.175 & 0.181 & 0.143 & 0.183 & 0.010 & 0.059 & -1.531 & 1.430 \\
\hline $\mathrm{COP}$ & 2611.31 & 64.56 & 0.864 & 17065.2 & 4959.9 & 1.899 & 1.940 & 2.495 \\
\hline PCG & 40894.3 & 1164.43 & 48.517 & 242566 & 72208.5 & 1.766 & 1.765 & 1.747 \\
\hline INF & 16.104 & 11.500 & 1.000 & 72.860 & 15.145 & 0.940 & 1.949 & 3.479 \\
\hline FDI & 550.840 & 128.500 & 7.900 & 4060.63 & 726.332 & 1.318 & 2.214 & 7.710 \\
\hline UEM & 8.028 & 5.100 & 1.900 & 27.300 & 6.157 & 0.767 & 1.413 & 1.015 \\
\hline IEC & 99.102 & 88.700 & 7.900 & 301.100 & 76.986 & 0.777 & 0.829 & 0.215 \\
\hline IMP & 66.822 & 80.300 & 10.000 & 140.000 & 40.327 & 0.603 & 0.009 & -1.194 \\
\hline LEN & 13.564 & 13.540 & 6.000 & 31.700 & 6.681 & 0.492 & 0.497 & -0.787 \\
\hline CAS & 0.011 & 0.007 & $5.4 \mathrm{e}-005$ & 0.042 & 0.010 & 0.966 & 1.052 & 0.445 \\
\hline EXD & 0.305 & 0.199 & 0.012 & 1.116 & 0.346 & 1.135 & 1.110 & -0.085 \\
\hline EXR & 0.094 & 0.064 & 0.009 & 0.313 & 0.086 & 0.916 & 0.999 & -0.039 \\
\hline NOI & 0.192 & 0.189 & 0.073 & 0.315 & 0.058 & 0.301 & 0.180 & -0.726 \\
\hline
\end{tabular}

Source: Computed by authors. Variables are as defined in Equation 11

Table 3. Result of the Unit Root test for Variables Used in the Analysis

\begin{tabular}{|c|c|c|c|c|c|c|}
\hline \multirow{3}{*}{$\begin{array}{l}\text { Logged } \\
\text { variables }\end{array}$} & \multicolumn{6}{|c|}{ ADF-GLS unit root test } \\
\hline & \multicolumn{3}{|c|}{ With constant and trend } & \multicolumn{3}{|c|}{ With constant } \\
\hline & Level & 1 st diff. & OT & Level & 1 st diff. & OT \\
\hline $\mathrm{LnHDI}_{\mathrm{t}}$ & -1.505 & $-7.226 * * *$ & $1(1)$ & -0.713 & $-6.319 * * *$ & $1(1)$ \\
\hline $\mathrm{LnODI}_{\mathrm{t}}$ & -1.416 & $-3.975 * * *$ & $1(1)$ & -0.476 & $-1.918 *$ & $1(1)$ \\
\hline $\mathrm{LnEDI}_{\mathrm{t}}$ & -2.141 & $-9.510 * * *$ & $1(1)$ & -0.823 & $-7.568 * * *$ & $1(1)$ \\
\hline $\mathrm{LnMED}_{\mathrm{t}}$ & -2.141 & $-9.510 * * *$ & $1(1)$ & -0.823 & $-7.568 * * *$ & $1(1)$ \\
\hline $\mathrm{LnCEI}_{\mathrm{t}}$ & -2.141 & $-9.510 * * *$ & $1(1)$ & -0.823 & $-7.568 * * *$ & $1(1)$ \\
\hline $\mathrm{LnCOP}_{\mathrm{t}}$ & -2.257 & $-7.652 * * *$ & $1(1)$ & 1.484 & $-7.010 * * *$ & $1(1)$ \\
\hline $\mathrm{LnPCG}_{\mathrm{t}}$ & -1.468 & $-5.140 * * *$ & $1(1)$ & 2.312 & $-4.691 * * *$ & $1(1)$ \\
\hline $\operatorname{LnINF}_{\mathrm{t}}$ & -3.52 & $-7.723 * * *$ & $1(1)$ & -2.492 & $-7.712 * * *$ & $1(1)$ \\
\hline $\mathrm{LnFDA}_{\mathrm{t}}$ & -3.06 & $-9.261 * * *$ & $1(1)$ & -0.607 & $-9.212 * * *$ & $1(1)$ \\
\hline $\operatorname{LnUEM}_{t}$ & -2.11 & $-7.928 * * *$ & 1(1) & -0.496 & $-6.905 * * *$ & $1(1)$ \\
\hline $\operatorname{LnIEC}_{t}$ & -1.522 & $-6.379 * * *$ & $1(1)$ & 0.614 & $-6.319 * * *$ & $1(1)$ \\
\hline $\operatorname{LnIMP}_{t}$ & -1.494 & $-8.016 * * *$ & $1(1)$ & 0.381 & $-7.704 * * *$ & $1(1)$ \\
\hline $\mathrm{LnLEN}_{\mathrm{t}}$ & -1.699 & $-7.241 * * *$ & $1(1)$ & -0.638 & $-7.259 * * *$ & $1(1)$ \\
\hline $\mathrm{LnCAS}_{\mathrm{t}}$ & -0.094 & $-7.861 * * *$ & 1(1) & -0.873 & $-4.754 * * *$ & $1(1)$ \\
\hline $\mathrm{LnEXD}_{\mathrm{t}}$ & -1.844 & $-9.069 * * *$ & $1(1)$ & -1.563 & $-8.941 * * *$ & $1(1)$ \\
\hline $\mathrm{LnEXR}_{\mathrm{t}}$ & -3.259 & $-8.042 * * *$ & $1(1)$ & -1.931 & $-7.995 * * *$ & $1(1)$ \\
\hline $\mathrm{LnNOI}_{\mathrm{t}}$ & -3.41 & $-11.013 * * *$ & $1(1)$ & -2.048 & $-10.823 * * *$ & $1(1)$ \\
\hline $1 \%$ & -3.755 & -3.758 & & -2.608 & -2.609 & \\
\hline
\end{tabular}

Note: OT means order of integration. Critical Value (CV) is defined at $1 \%$ significant level and asterisks $* * *$ represents $1 \%$ significance level. Variables are as defined previously in equation 11.

Table 4. Exponential Trend Analysis of Agricultural diversification indices in Nigeria

\begin{tabular}{|c|c|c|c|c|c|}
\hline Variables & LnHDI & $\operatorname{LnODI}$ & $\operatorname{LnEDI}$ & LnMEI & $\operatorname{LnCDI}$ \\
\hline Constant & $-0.308(-11.55) * * *$ & $-1.009(-7.74)^{* * *}$ & $-1.124(-93.83) * * *$ & $-1.599(-133.6)$ & $-1.823(-152.2) * * *$ \\
\hline Time & $0.005(5.65)^{* * *}$ & $0.023(5.68) * * *$ & $0.003(7.52)^{* * *}$ & $0.003(7.52)^{* * *}$ & $0.003(7.52)^{* * *}$ \\
\hline F- cal. & $31.923 * * *$ & $32.266^{* * *}$ & 56.503 & 56.503 & 56.503 \\
\hline R-square & 0.376 & 0.378 & 0.516 & 0.516 & 0.516 \\
\hline Exp. GR (\%) & 0.5 & 2.3 & 0.3 & 0.3 & 0.3 \\
\hline \multicolumn{6}{|c|}{ Quadratic trend } \\
\hline \multicolumn{6}{|c|}{ Equation estimates } \\
\hline Constant & $-0.469(-16.30) * * *$ & $-1.829(-13.53) * * *$ & $-1.191(-85.38) * * *$ & $-1.67(-119) * * *$ & $-1.889(-135.5) * * *$ \\
\hline Time & $0.022(9.15)^{* * *}$ & $0.109(9.82)^{* * *}$ & $0.009(8.57)^{* * *}$ & $0.009(8.57)^{* * *}$ & $0.009(8.57) * * *$ \\
\hline Time Square & $-0.0003(-7.41) * * *$ & $-0.002(-8.00) * * *$ & $-0.0001(-6.33) * * *$ & $-0.0001(-6.3)^{* * *}$ & $-0.0001(-6.33) * * *$ \\
\hline F- cal. & $59.597 * * *$ & $67.354 * * *$ & $69.16^{* * *}$ & $69.16 * * *$ & $69.16^{* * *}$ \\
\hline R-square & 0.696 & 0.721 & 0.727 & 0.727 & 0.727 \\
\hline
\end{tabular}

Note: Values in bracket represent t-values. The asterisks * and *** represent $10 \%$ and $1 \%$ significance levels respectively 
Sunday B. Akpan et al. / American Journal of Economics and Business Administration 2015, 7 (2): 77.93 DOI: 10.3844/ajebasp.2015.77.93

Table 5. Long run estimates of agricultural diversification equations

\begin{tabular}{|c|c|c|c|}
\hline Variables & HDI & ODI & $\mathrm{EDI}=\mathrm{MED}=\mathrm{CEI}$ \\
\hline Constant & $-0.608(-2.204)^{* *}$ & $-4.321(-2.794)^{* * *}$ & $0.186(3.1418)^{* * *}$ \\
\hline$C O P_{t}$ & $-0.054(-1.90)^{*}$ & $-0.529(-3.332)^{* * *}$ & $-0.192(-3.435)^{* * *}$ \\
\hline$P C G_{t}$ & $0.035(1.52)$ & $0.452(3.490)^{* * *}$ & $0.022(4.926)^{* * *}$ \\
\hline$I N F_{t}$ & $0.033(2.56)^{* * *}$ & $0.116(1.852)^{*}$ & $-0.0002(-0.112)$ \\
\hline$F D I_{t}$ & $-0.0001(-0.01)$ & $-0.056(-0.714)$ & $-0.007(-2.478)^{* *}$ \\
\hline$U E M_{t}$ & $0.020(0.69)$ & $0.313(1.909)^{*}$ & $0.003(0.479)$ \\
\hline$I E C_{t}$ & $-0.039(-1.23)$ & $-0.204(-1.135)$ & $0.013(2.111)^{* *}$ \\
\hline$I M P_{t}$ & $0.208(4.49)^{* * *}$ & $1.014(3.899)^{* * *}$ & $0.004(0.431)$ \\
\hline$L E N_{t}$ & $-0.085(-1.68)^{*}$ & $-0.124(-0.435)$ & $0.013(1.267)$ \\
\hline$C A S_{t}$ & $0.022(1.77)^{*}$ & $0.162(2.295)^{* *}$ & $0.003(1.397)$ \\
\hline$E X D_{t}$ & $-0.017(-1.42)$ & $-0.053(-0.808)$ & $0.003(1.249)$ \\
\hline$E X R_{t}$ & $0.051(4.36)^{* * *}$ & $0.141(2.146)^{* *}$ & $-0.003(-1.082)$ \\
\hline $\mathrm{NOI}_{t}$ & $-0.038(-1.52)$ & $-0.284(-2.011)^{*}$ & $-0.011(-2.244)^{* *}$ \\
\hline$R$-Square & 0.879 & 0.841 & 0.839 \\
\hline F-Cal. & $25.375 * * *$ & $18.552 * * *$ & $18.220 * * *$ \\
\hline LM (autocorrelation) & $4.131 * *$ & $9.516^{* * *}$ & 0.892 \\
\hline RESET test & $25.676^{* * *}$ & $118.33 * * *$ & $20.791 * * *$ \\
\hline DWatson & 1.433 & 1.027 & 1.716 \\
\hline \multicolumn{4}{|c|}{$\begin{array}{l}\text { ADF-GLS unit root test for errors } \\
\text { generated from above equations }\end{array}$} \\
\hline Constant & $-4.704 * * *$ & $-2.253 * *$ & $--5.652 * * *$ \\
\hline Constant + trend & $-5.239 * * *$ & $-3.468 * *$ & $-6.087 * * *$ \\
\hline
\end{tabular}

Note: Variables are expressed in logarithm. Values in bracket represent t-values. Asterisks *, ** and *** represent 10,5 and $1 \%$ significance levels respectively. Variables are as described in equation 11

Table 6. Johansen cointegration test results

\begin{tabular}{|c|c|c|c|c|c|c|}
\hline $\begin{array}{l}\text { Hypotheses } \\
\text { (Null) }\end{array}$ & (Alternative) & Eigenvalue & $\begin{array}{l}\text { Trace } \\
\text { Statistic }\end{array}$ & $\begin{array}{l}0.05 \\
\text { Critical Value }\end{array}$ & $\begin{array}{l}\text { Max-Eigen } \\
\text { Statistic }\end{array}$ & $\begin{array}{l}0.05 \\
\text { Critical Value }\end{array}$ \\
\hline $\mathrm{r}=0$ & $r \geq 1$ & 0.9342 & $585.1033 * * *$ & 334.9837 & $144.1824 * * *$ & 76.5784 \\
\hline $\mathrm{r} \leq 1$ & $r \geq 2$ & 0.8371 & $440.9209 * * *$ & 285.1425 & $96.1669 * * *$ & 70.5351 \\
\hline$r \leq 2$ & $r \geq 3$ & 0.8067 & $344.7540 * * *$ & 239.2354 & $87.1095 * * *$ & 64.5047 \\
\hline$r \leq 3$ & $r \geq 4$ & 0.6826 & $257.6445^{* * *}$ & 197.3709 & $60.8194 * *$ & 58.4335 \\
\hline$r \leq 4$ & $\mathrm{r} \geq 5$ & 0.6450 & $196.8251 * * *$ & 159.5297 & $54.8949 * *$ & 52.3626 \\
\hline $\mathrm{r} \leq 5$ & $r \geq 6$ & 0.4796 & $141.9302 * * *$ & 125.6154 & 34.6198 & 46.2314 \\
\hline$r \leq 6$ & $r \geq 7$ & 0.4411 & $107.3104^{* * *}$ & 95.7537 & 30.8308 & 40.0776 \\
\hline$r \leq 7$ & $r \geq 8$ & 0.3628 & $76.47960 * *$ & 69.8189 & 23.8859 & 33.8769 \\
\hline $\mathrm{r} \leq 8$ & $r \geq 9$ & 0.3061 & $52.59372 * *$ & 47.8561 & 19.3704 & 27.5843 \\
\hline$r \leq 9$ & $r \geq 10$ & 0.2551 & $33.22329 * *$ & 29.7971 & 15.6099 & 21.1316 \\
\hline $\mathrm{r} \leq 10$ & $r \geq 11$ & 0.1728 & $17.61333 * *$ & 15.4947 & 10.0518 & 14.2646 \\
\hline $\mathrm{r} \leq 11$ & $r \geq 12$ & 0.1330 & $7.561489 * * *$ & 3.8415 & $7.5615^{* * *}$ & 3.84147 \\
\hline
\end{tabular}

Note: Trace test indicates 12 co-integrating equations at $5 \%$ significant level. * denotes rejection of the null hypothesis at 0.05 level. **MacKinnon et al. (1999) p-values

Table 7. Determination of optimum lag length

\begin{tabular}{llllll}
\hline Lag & Loglike & P(LR) & AIC & BIC & HQC \\
\hline 1 & 377.829 & - & -13.1932 & -11.3576 & -12.4942 \\
2 & 387.953 & 0.0164 & -13.2381 & -11.0584 & -12.4081 \\
3 & 423.853 & 0.0000 & -14.3141 & -11.7902 & -13.3530 \\
4 & 440.591 & 0.0001 & -14.6237 & -11.7556 & $-13.5315^{*}$ \\
5 & 452.438 & 0.0048 & $-14.7375^{*}$ & -11.5253 & -13.5143 \\
\hline
\end{tabular}

The asterisks below indicate the best (that is, minimized) values of the respective information criteria, AIC = Akaike Criterion, $\mathrm{BIC}$ $=$ Schwarz Bayesian Criterion and HQC $=$ Hannan-Quinn Criterion 


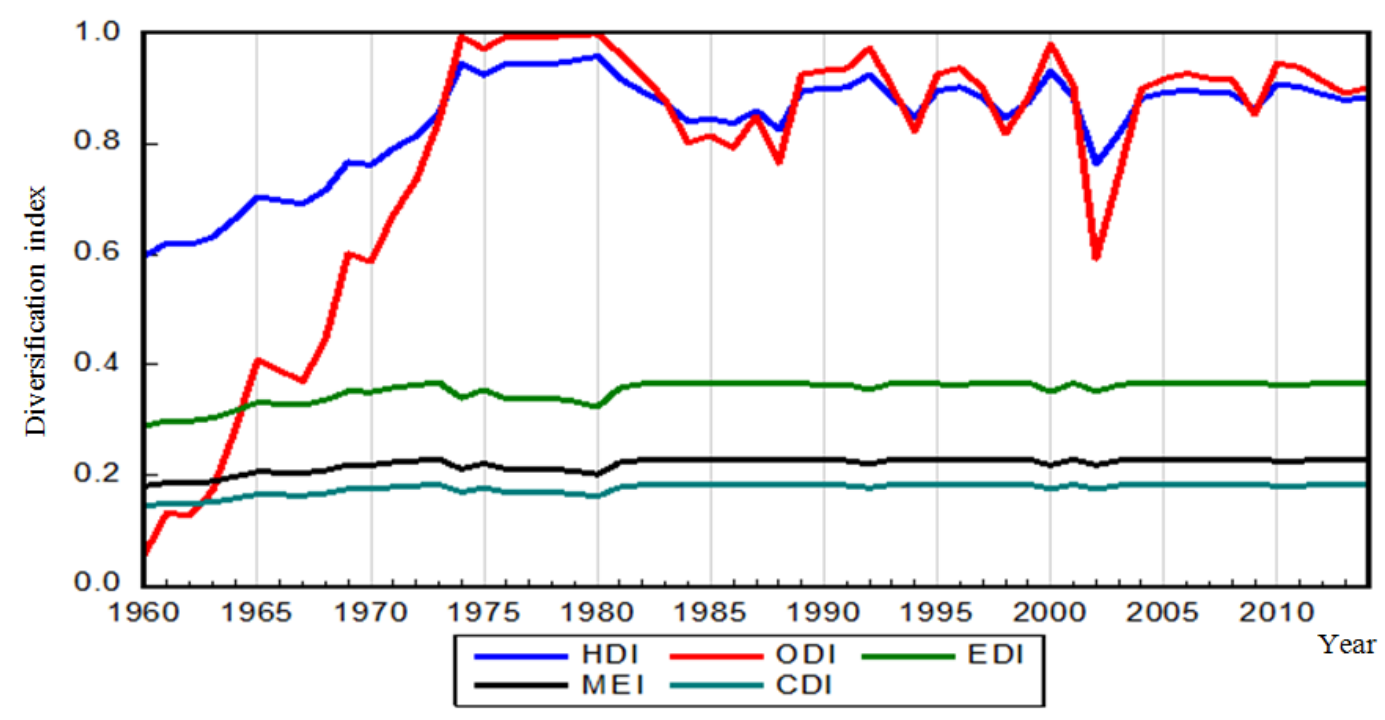

Fig. 1. Trend in HDI, ODI, EDI, MEI and CDI in Agricultural sector in Nigeria (1960-2014)

However the index assumed progressive upward trend following increase in crude oil exploration and exploitation in the country. The period 1976 to 1980 witnessed almost total neglect of the agricultural sector in the country. In this period, the contribution of agricultural sector to the country GDP stood at $28.52 \%$. The domestic agricultural production could not sustained domestic consumption, as the result Nigeria became net importer of agricultural commodities. During this period, the country also witnessed high volatility in macroeconomic variables. For instance, inflation rate was $33.33 \%$ in 1975 ; it stood at $21.2 \%$ in 1976 and lowered to $9.9 \%$ in 1980 . Following these distortions, disinvestment occurred in agricultural sectors; ruralurban youth migration increased leading to labour constrained in the rural areas. Farmers' real income shrinks while agriculture was relegated to the bottom in exchange to the lucrative petroleum and natural gas sub sectors (CBN, 2005; Udoh and Elias, 2011).

The fluctuations in HDI and ODI witnessed declined trend in the period 1980 to 1988 . This period marked a significant moderation in the economic environment and industrial policy in Nigeria. Imbalances in both internal and external economy structures prevailed in the country. As a consequence, the output of the industrial sector shrinks (Nwosu, 1992). This period ushered in the Structural Adjustment Programme (SAP) and subsequent liberalization of the Nigerian economy. Several agricultural policies were implemented to revive the country's agricultural sector and the economy. During this period agricultural intensification mounted while the diversification was distorted. Thereafter, the agricultural diversification indices showed undulated trend till 2014. It is observed that, these fluctuations were consonance with government policies and interest in agricultural activities. Though the indices expressed a trough depression in 2002, it however recovered and later moved above 0.8 marks till 2014. The trend in EDI was similar in several aspects as in HDI an ODI.

\section{Co-Integration Test of Diversification Index in Nigeria}

The study applied the Engle and Granger two-step technique and Johansen cointegration approach to examine co-integration relationship among time series specified. The result of the Engle and Granger two-step technique of cointegration test for each of the index is presented in lower portion of Table 5. The results showed that at $1 \%$ significance level of critical value, the Engle-Granger cointegration tests reject the null hypothesis of no cointegration. Hence, there exists a long run equilibrium relationship between the agricultural diversification index and selected macroeconomic variables in Nigeria. The results showed that at $1 \%$ probability level of significance, the Augmented Dicker-Fuller -GLS (ADF-GLS) test for the residuals at level is greater than the critical value at $1 \%$ probability value $(-4.05)$.

For the Johansen co-integration approach, the tabulated trace and maximum eigenvalue test statistics were significant at various rank levels. The result as presented in Table 6 revealed that the calculated trace test and maximum eigenvalue test statistics are greater than the critical values at various conventional probability levels.

The result shows that there are at least eleven cointegrating vectors. This implies that, the diversification indices will attain a stable state in the long run following short run fluctuation in some macroeconomic variables in Nigeria. However, the upper portion of Table 5 presented the long run estimates for each of 
the diversification index equation. The estimated coefficients represent the long run agricultural diversification index elasticity with respect to each specify macroeconomic variable in the Nigeria's economy.

Generating Optimal Lag- Length for the CoIntegrating Variables

Appropriate lag length for the co-integrating series is needed to generate the Error Correction Model (ECM) forthe co-integrating variables. The Akaike Criterion (AIC), Schwarz Bayesian Criterion (BIC) and HannanQuinn criterion (HQC) test were employed to determine the appropriate lag length. The test result as shown in Table 7 indicates that the optimum lag length appropriate for generating the ECM is at lag 4.

\section{Error Correction Model for Agricultural Diversification Index in Nigeria}

The primary reason for estimating the ECM model was to capture the dynamics in the agricultural diversification index equations and identify the speed of adjustment as a response to departure from the long-run equilibrium. The study adopted Hendry's (1995) approach in which an over parameterized model is initially estimated and then gradually reduced by eliminating insignificant lagged variables until appropriate model is obtained. The result of the exercise is presented in Tables 8. The slope coefficients of the error correction terms are negative and statistically significant at conventional levels for HDI, ODI and EDI equations.

The result validates the existence of a stable long-run symmetric equilibrium relationship among the time series in each of the agricultural diversification equation and also indicates that the index is sensitive to the departure from its equilibrium value in the previous periods. The slope coefficient of the error correction term in each of the agricultural diversification index equation represents the speed of adjustment and also is consistent with the hypothesis of convergence towards the long-run equilibrium once the respective equation is disturbed. The diagnostic test for the ECM model revealed $\mathrm{R}^{2}$ value of 0.475 for HDI, 0.229 for ODI and 0.552 for EDI. The Durbin-Watson value for each equation indicates significant effect of serial correlation. The ECM model has been shown to be robust against residual autocorrelation. Therefore, the presence of autocorrelation does not affect the estimates (Laurenceson and Chai, 2003).

Long Run and Short Run Elasticity of Agricultural Diversification Index with Respect to some Macroeconomic Variables in Nigeria

The Long run model results revealed that, agricultural diversification has significant negative inelastic relationship with respect to the annual Crude
Oil Prices (COP); lending rate of commercial Bank (LEN); foreign direct investment in agricultural sector (FDI) and value of non-oil import (NOI) in Nigeria. The result implies that, as oil price increases, agricultural diversification decrease. This is because most of the country's real sector policies focused on agricultural production; hence increase in oil price implied increase in the country's revenue and probably increment in agricultural investment. This situation increases agricultural intensification and reduce diversification too.

Also, increase in the lending rate of commercial Banks reduces agricultural diversification index in Nigeria. Increase in the lending rate of Banks reduces the accessibility to agricultural credit by farmers. Since most farmers in the country do not have sufficient collateral to obtain loan, thus a rise in lending rate will encourage outward migration from farming activities (the most vulnerable group is the youth) to a more lucrative sectors like crude oil and natural gas as well as service sector. In addition, the gestation period of most agricultural activities retard Banks'interest on disbursement of loan facilities to farmers. This action discourages a lot of people from embarking in agricultural production, hence considering occupational diversification as the best option.

Similarly increase in foreign direct investment in agricultural sector inversely related to agricultural diversification in Nigeria. This implies that, as FDI increases, the mechanization of agricultural activities is boosted too. Significant portion of agricultural activities became mechanized (e.g., in poultry production) and redundancy among labour increased. This lead to possible occupational migration (diversification) among affected workers. Alternatively, farming activities in the country are organized by mostly rural poor farmers who cannot afford modern technologies used in farming. As a way to encourage agricultural intensification, if modern technologies which are associated with foreign direct investment are made available to farmers to intensify production; diversification will be reduced.

The long run model also revealed that, the coefficient of non-oil import exhibited significant negation influenced on agricultural diversification in Nigeria. The result satisfies a priori expectation. Increase in non-oil imports can result in dumping, thereby stiffening the domestic production of goods and services. It lead to infiltration of the domestic market with cheap and varieties of agricultural commodities. A typical example in Nigeria is the proliferation of imported rice in the country rice markets. This action has nearly buried the domestic rice market. Currently, government is considering outright banned on rice importation in order to develop domestic rice production. 
Table 8. Short run estimates of Agricultural Diversification equations

\begin{tabular}{llll}
\hline Variables & $H D I$ & $O D I$ & $E D I=M E D=C E I$ \\
\hline Constant & $-0.003(-0.345)$ & $0.027(0.831)$ & $-0.006(-0.141)$ \\
$\Delta$ LnHDIt- & $0.187(1.28)$ & - & - \\
$\Delta$ Ln ODIt-1 & - & $0.144(1.206)$ & - \\
$\Delta$ Ln EDIt-1 & - & - & $-225(-1.602)$ \\
$\Delta$ Ln COPt & $0.023(0.948)$ & $-0.006(-0.055)$ & $-0.004(-0.893)$ \\
$\Delta$ LnPCG $_{t}$ & $0.022(0.519)$ & $-0.002(-0.014)$ & $0.005(1.169)$ \\
$\Delta$ LnINF $_{t}$ & $0.016(1.963)^{*}$ & $0.044(1.340)$ & $-0.001(-0.737)$ \\
$\Delta$ LnFDI $_{t}$ & $0.007(0.725)$ & $0.017(0.435)$ & $-0.002(--1.010)$ \\
$\Delta$ LnUEM $_{t}$ & $-0.009(-0.392)$ & $0.006(0.061)$ & $-0.03(-0.512)$ \\
$\Delta$ LnIEC $_{t}$ & $-0.038(-1.178)$ & $-0.122(-0.949)$ & $0.016(3.056)^{* * *}$ \\
$\Delta$ LnIMP $_{t}$ & $0.067(1.535)$ & $0.258(1.471)$ & $-0.015(-1.919)^{*}$ \\
$\Delta$ LnLEN $_{t}$ & $-0.057(-1.402)$ & $-0.159(-0.970)$ & $0.004(0.546)$ \\
$\Delta$ LnCAS $_{t}$ & $0.004(0.361)$ & $0.007(0.153)$ & $-0.002(-0.936)$ \\
$\Delta$ LnEXD $_{t}$ & $-0.006(-0.776)$ & $-0.013(-0.385)$ & $0.003(1.594)$ \\
$\Delta$ LnEXR $_{t}$ & $0.023(1.987)^{*}$ & $0.053(1.199)$ & $-0.002(-1.211)$ \\
$\Delta$ LnNOI $_{t}$ & $-0.006(-0.313)$ & $-0.004(-0.058)$ & $0.012(2.799)^{* * *}$ \\
ECMt- $_{\text {R- Square }}$ & $-0.523(-3.359)^{* * *}$ & $-0.229(-2.044)^{* *}$ & $-0.480(-3.023)^{* * *}$ \\
Loglik. $_{\text {DW test }}$ & 0.475 & 0.229 & 0.552 \\
\hline Note Vari & 109.814 & 35.909 & 192.373
\end{tabular}

Note: Variables are expressed in logarithm. Variables are as described in equation 11.Asterisks *, ** and *** represent 10,5 and $1 \%$ significance levels respectively

On the other hand, agricultural diversification has a significant direct relationship with annual inflation rate (INF), index of Manufacturing Production (IMP), Credit to Agricultural Sector (CAS), External Reserves (EXR), annual per capita GDP, (PCG), annual unemployment rate (UEM) and Index of Energy Consumption (IEC). The result implies that, these macroeconomic variables are potential positive drivers of agricultural diversification in Nigeria. For instance, increase in inflation will lower the real income of farmers and raise the nominal price of farm resources through the spilled over or multiplier effects thereby discouraging investment in the sector. It is known that, the supply of most agricultural commodities are elastic, while demand remains inelastic, hence during period of high inflation, most farmers will diversify to non-farming activities due to low real income.

In a similar way, the result of the relationship between agricultural diversification and index of manufacturing production connotes that; increase in industrial production will increase the agricultural diversification tendencies in the economy. Increase in industrial production will stimulate a multiplier chain in job generation. Excess labour force (mostly youth) in agricultural sector is then trapped in these activities, thereby stimulating diversification.

The slope coefficient of credit to agricultural sector surprisingly skews from a priori expectation derived from economic theory. It is expected that, increase in agricultural credit should increase investment activities in the sector which will lead to increase in output; but a contrary result was obtained. This result could be attributed to several factors peculiar to the Nigeria's economy. Some of these factors includes: increase corruption among government officials, poor policy implementation, weak institutional framework and increase poverty among farmers. These factors affect credit flow in several ways such as; prevention of real farmers from accessing credit from government credit institutions and diversion of credits among others.

Agricultural diversification also showed positive correlation with external reserves in Nigeria. Increase in external reserves could means that, the domestic economy do not have sufficient investment opportunities. Since Nigeria is basically an agrarian society, increase in external reserves will implies that, the government is not investing sufficiently in agricultural sector since there are many untapped opportunities in this sector. During this period, the economy will re-adjust to stimulate investment in other sectors while disinvesting in agricultural sector.

The per capita GDP, that proxy aggregate demand strength and economic growth fluctuates in the same direction as agricultural diversification. Increase in per capita GDP means increase in consumers' real income, purchasing power and preference/choice as well as utility. Since consumers are considered to be rational, they will go for more quality and satisfying foreign agricultural commodities if their demand capabilities increase. Following this, the real income of domestic farmers will shrink, leading to lower production and subsequent diversification in the long run. 
Agricultural sector serves as a reservoir of employment potentials; but in Nigeria white collar jobs are preferred by the youth population. Nigeria has a weak industrial and service sectors and there is increasing rural-urban youth migration. The rate of urban unemployment in Nigeria is one of the highest in the sub-Saharan Africa. Also literature in Nigeria has reported that, the rural farming population is ageing and farm labour constrained is on the raise, while millions of unemployed idled youth cluster in the urban and suburban areas of the country. By implication, the mounting rate of unemployment in the country connotes increase outward of active labour force from the rural area to urban areas. In the absent of incentives to rural farmers, increase in unemployment will means increase in agricultural diversification or reduction in agricultural intensification.

The result also showed that, increase in electricity consumption increase agricultural diversification in Nigeria. The result satisfies a priori expectation, because increase in energy consumption will trigger small scale businesses and facilitate food processing or value addition. Agricultural production has a long gestation period and young people will prefer fast yielding businesses to agricultural activities. Hence, increase in energy consumption will lead to exodus of young vibrant labour from agricultural sector to the informal farmers. Thus without sufficient incentives and sound policy frame work and institution, continuous increase in energy consumption in the country will lead to increase in agricultural diversification in the long run.

\section{The Short Run Model}

The short run elasticity of coefficient revealed that, inflation rate (INF); External Reserves (EXR); and NonOil Imports (NOI) has significant short run positive relationship with agricultural diversification in Nigeria. This means that, increase in non-oil imports increases the tendency of dumping and unfavorable domestic competition in the agricultural sector in a short run. In the absence of appropriate import polices, increase in "NOI" will lead to low productivity in agricultural sector and subsequent diversification. On the other hand, Index of Energy Consumption (IEC) and Index of Manufacturing Production (IMP) exhibited negative influence on agricultural diversification in the short run. These results could be due to the poverty level and the rural nature of agricultural activities as well as the poor infrastructural facilities in most rural farming communities in the country. For instance, sudden increase in energy consumption can instantly boost agricultural processing and value addition (intensification) among farmers hence reduce diversification drive.
A Ten-Year out Sample Forecast of Agricultural Diversification Index in Nigeria (2015 to 2024)

A ten-year trend forecast of HDI, ODI and EDI is shown in Fig. 2 to 4 respectively. The diagrams showed a progressive growth in trend of agricultural diversification indexes in Nigeria. This means that, by stabilizing movement in macroeconomic variables as well as other important variables in the Nigeria's economy, agricultural diversification will increase in the next ten years. The pattern of growth in the three indices is similar and moved progressively from 2015 to 2025 . This result connotes that, citerisparibus; the country is capable of experiencing positive growth in industrial sector, service, building and construction as well as the whole sale and retailed trade sectors. It means that, the contribution of these sectors to the country's GDP can witnessed a progressive boom in the period 2015 to 2025 if stability in macroeconomic variables among others is achieved. The confidence intervals showed a two-sided steady growth from 2015 to 2025 . This means that, the country agricultural diversification index is also capable of trending upward or downward depending on the economic situation in the country. This indicates that, if sound macroeconomic policies are implemented, the economy is capable of tilting away from the dominancy of agricultural sector in the GDP to less contributive sectors. The result has a lot of implications on the current and future economy plans for the government of Nigeria. It implies that, there are viable potentials outside agricultural sector to grow the economy to achieve the long term objective of industrialization and poverty reduction.

However, the study could not establish whether agricultural intensification will grow positively or negatively within this forecast period. Whatever the growth pattern in agricultural sector, the result implies that, others sectors that contributed to the country GDP will increase their shares given stable economic environment in the country.

The predicted value of agricultural diversification index did not significantly differ from the actual values. The result revealed that, there is considerable stability in agricultural diversification in Nigeria.

\section{Variance Decomposition and Impulse Analysis of Agricultural Diversification in Nigeria}

Results in Table 9 and 10, showed relative contributions of specified macroeconomic variables to the variation in the agricultural diversification index in Nigeria. Analysis revealed that, in the second period, the impact of non-oil imports was the major exogenous contributor to changes in Herfindhal agricultural diversification index in the short run. 
Sunday B. Akpan et al. / American Journal of Economics and Business Administration 2015, 7 (2): 77.93 DOI: 10.3844/ajebasp.2015.77.93

Table 9. Variance Decomposition of HDI

\begin{tabular}{|c|c|c|c|c|c|c|c|c|c|c|c|c|c|c|}
\hline Period & S.E & HDI & COP & PCG & INF & FDI & UEM & IEC & IMP & LEN & CAS & EXD & EXR & NOI \\
\hline$\overline{1}$ & 0.036 & 100.000 & 0.000 & 0.000 & 0.000 & 0.000 & 0.000 & 0.000 & 0.000 & 0.000 & 0.000 & 0.000 & 0.000 & 0.000 \\
\hline 2 & 0.047 & 93.719 & 2.196 & 0.148 & 0.460 & 0.512 & 0.425 & 0.889 & 0.454 & 0.372 & 0.001 & 0.047 & 0.642 & 0.136 \\
\hline 3 & 0.055 & 76.906 & 4.419 & 2.603 & 0.648 & 1.322 & 0.389 & 1.026 & 7.580 & 2.194 & 0.086 & 0.229 & 2.404 & 0.192 \\
\hline 4 & 0.065 & 60.635 & 5.657 & 5.560 & 0.551 & 1.218 & 0.289 & 0.913 & 14.25 & 2.619 & 0.994 & 0.196 & 5.873 & 1.240 \\
\hline 5 & 0.069 & 57.313 & 5.031 & 5.095 & 0.975 & 1.297 & 0.359 & 2.009 & 15.46 & 3.053 & 0.880 & 0.175 & 6.748 & 1.601 \\
\hline 6 & 0.073 & 55.552 & 4.473 & 4.538 & 0.978 & 1.163 & 0.693 & 2.144 & 16.16 & 2.961 & 1.599 & 0.163 & 7.226 & 2.348 \\
\hline 7 & 0.078 & 52.431 & 3.966 & 7.259 & 0.876 & 1.069 & 0.710 & 1.928 & 16.71 & 3.243 & 1.497 & 0.153 & 7.799 & 2.360 \\
\hline 8 & 0.080 & 50.255 & 3.926 & 6.998 & 0.932 & 1.277 & 0.673 & 2.372 & 16.58 & 3.275 & 1.646 & 0.171 & 9.455 & 2.439 \\
\hline 9 & 0.081 & 48.692 & 3.802 & 6.783 & 1.027 & 2.504 & 0.707 & 2.353 & 16.29 & 3.216 & 2.001 & 0.168 & 10.04 & 2.417 \\
\hline 10 & 0.083 & 46.269 & 3.674 & 7.925 & 1.057 & 3.661 & 1.068 & 2.559 & 15.75 & 3.167 & 2.151 & 0.161 & 10.25 & 2.313 \\
\hline
\end{tabular}

Source: Result generated from EView

Table 10. Variance decomposition of ODI

\begin{tabular}{|c|c|c|c|c|c|c|c|c|c|c|c|c|c|c|}
\hline Period & S.E & ODI & $\mathrm{COP}$ & PCG & INF & FDI & UEM & IEC & IMP & LEN & CAS & EXD & EXR & NOI \\
\hline 1 & 0.084 & 100. & .000 & 0.000 & 000 & 0.00 & 0.000 & 0.000 & 0.000 & 00 & 0.000 & .000 & .000 & 0.000 \\
\hline 2 & 0.111 & & .509 & 0.6 & & & 242 & 0.252 & & & & 1 & 52 & 0.219 \\
\hline 3 & 0 & & 3.338 & 2.0 & & & 255 & 0.2 & & & & 0.064 & 68 & 0.218 \\
\hline 4 & 0 & 63.6 & 9 & 4.4 & & & 21 & 0.5 & & & & 48 & 81 & 1.016 \\
\hline 5 & 0. & 6 & 201 & 4. & & & 49 & 0.6 & & & & & 23 & 73 \\
\hline 6 & 0 & & & 4.499 & 036 & 1. & 20 & 0.8 & & & 5 & 0. & 666 & 1.586 \\
\hline 7 & 177 & 6. & 93 & 6.347 & 8 & 2 & 495 & 0.854 & 14 & 2.777 & 47 & 0.041 & .307 & 1.533 \\
\hline 8 & 181 & 7 & 504 & 6.524 & 1.871 & 1.947 & 0.520 & 0.850 & 14.70 & 2.773 & 1.398 & 0.089 & 0.01 & 1.521 \\
\hline y & 85 & 24 & 386 & 6.3 & 1.953 & 3.628 & 0.715 & 0.821 & 14.29 & 2.703 & 1.527 & 0.102 & 0.63 & 1.474 \\
\hline 10 & 0.189 & 49.671 & 3.568 & 6.580 & 1.974 & 5.141 & 1.239 & 1.452 & 13.79 & 2.612 & 1.764 & 0.099 & 10.69 & 1.406 \\
\hline
\end{tabular}

Source: Result generated from EView

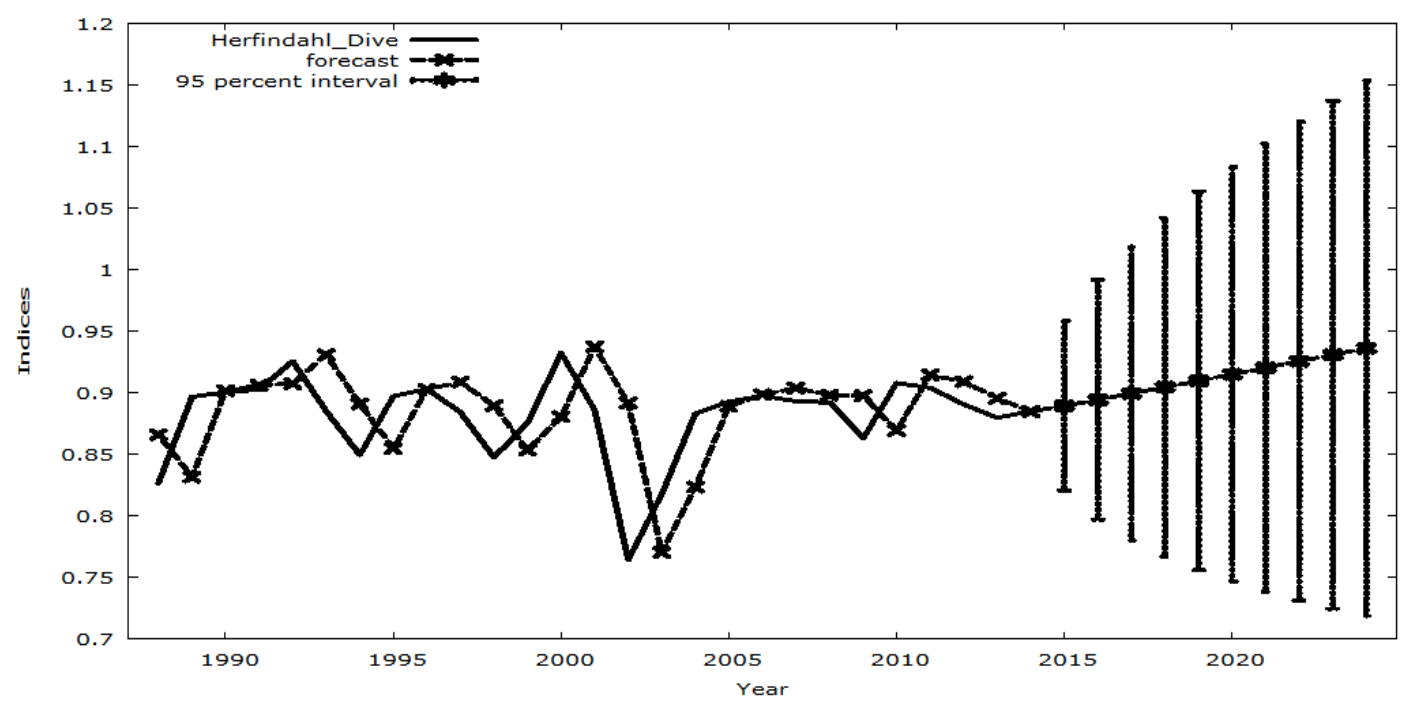

Fig. 2. A ten-year forcast of HDI in Nigeria (2015-2024)

During this period, increase in unemployment, energy consumption, credit to agricultural sector and manufacturing sector played insignificant role in HDI variation. In the long-run, external debt, energy consumption, non-oil imports, demand shock and foreign direct investment were paramount in altering agricultural diversification in Nigeria.

A careful look at the result reveals that, shocks in the diversification indexes constitute significant source of variation in itself both in the short and long-run. For instance, HDI witnessed about $99.83 \%$ shocked in period 2 and $97.63 \%$ in ODI; while 99.71 and $95.10 \%$ were obtained for both indexes respectively in period 10th. Shocks from unemployment constitute the least source of variations in agricultural diversification.

The examination of variations in agricultural diversification in the country in both short run and long run was further complemented by the impulse analysis conducted on diversification indices. 


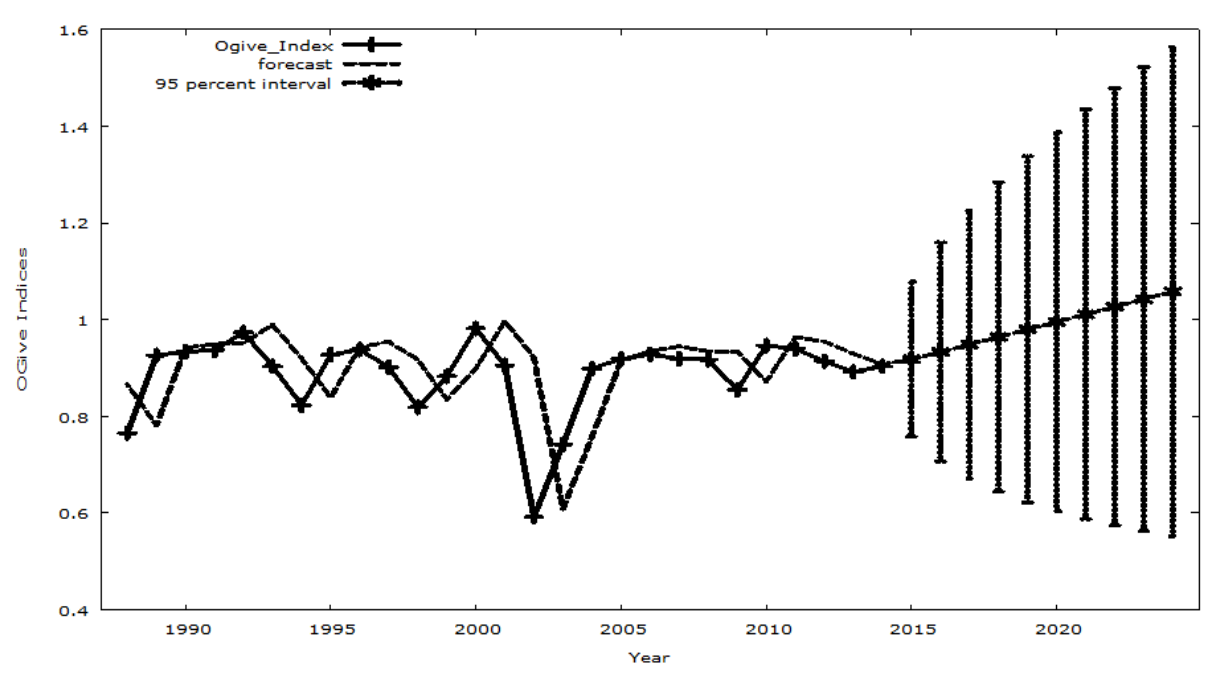

Fig. 3. A ten-year forecast of ODI in Nigeria (2015-2024)

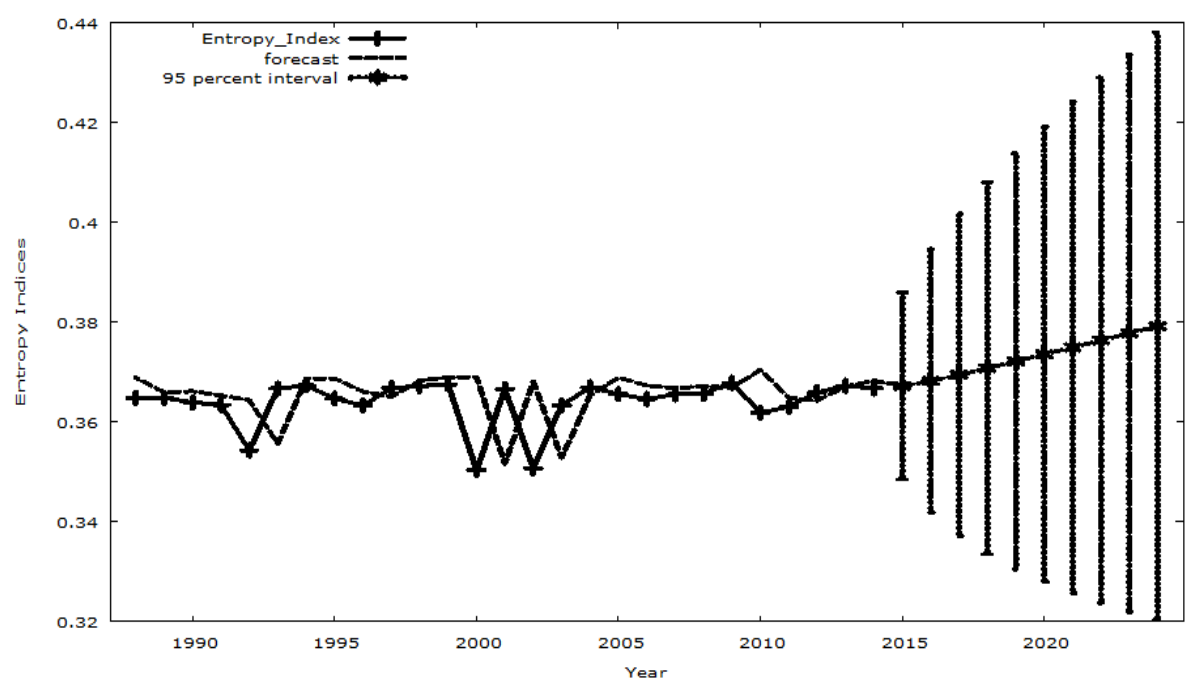

Fig. 4. A ten-year forecast of EDI in Agricultural sector in Nigeria (2015-2024)

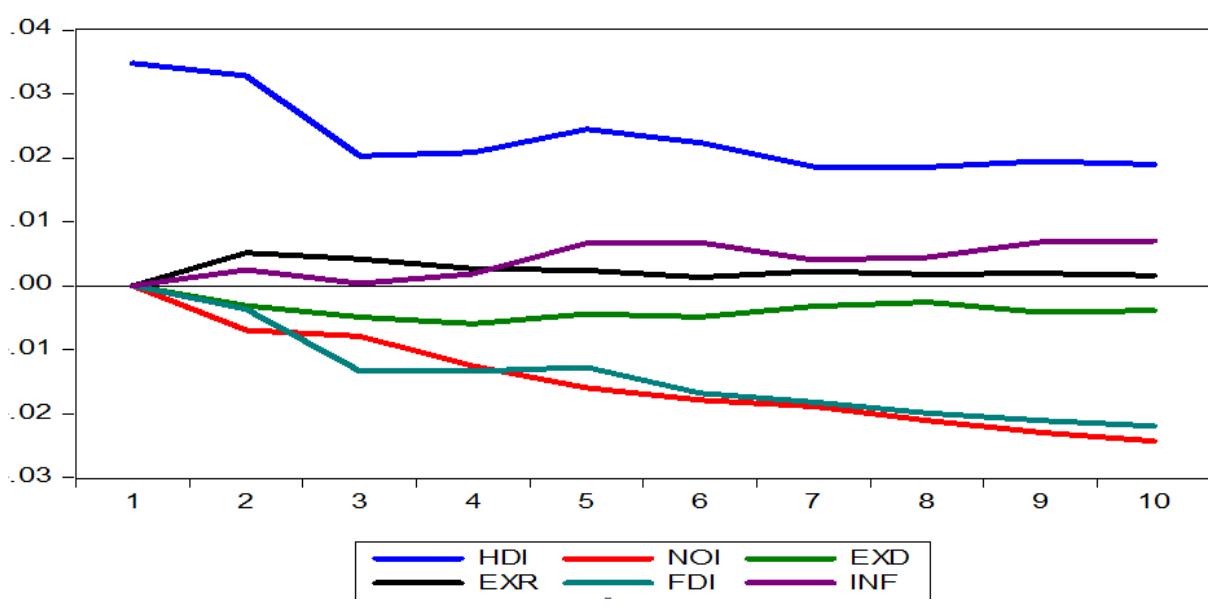

Fig. 5. Response of HDI to Cholesky one S.D. innovations 


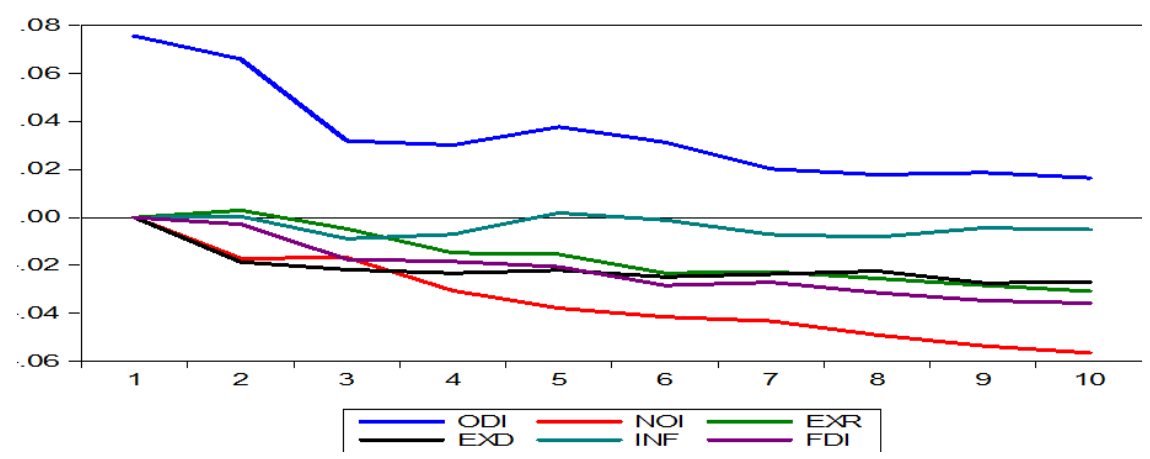

Fig. 6. Response of ODI to Cholesky one S.D. innovations

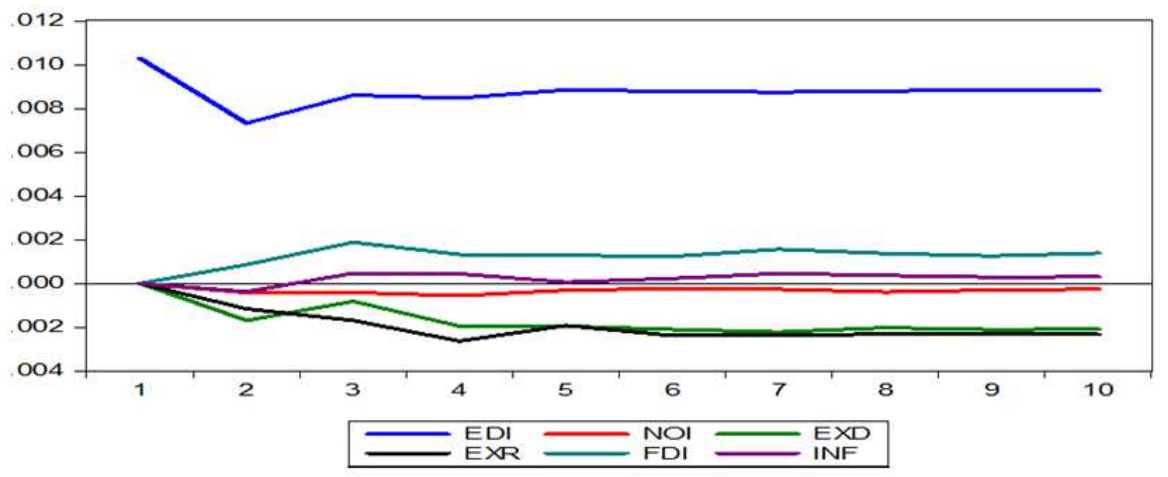

Fig. 7. Response of EDI to Cholesky one S.D. innovations

The impulse response of Agricultural diversification to changes in some macroeconomic variables is shown in Fig. 5 to 7 . The innovation accounting test results revealed that the HDI, ODI and EDI fluctuate downward from period one to period ten. The effect of shocks in inflation in the three indexes showed an average positive impact in both short and long run periods. The responses of HDI and ODI to shock in non-oil imports indicated short and long run negative influence respectively. However, the effect of foreign direct investment in ODI and HDI connotes negative effect in HDI and ODI in short and long run periods.

However, the result displayed by the impulse response analyses is in consonance with the results earlier reported in the cointegration and error correction model as well as the variance decomposition.

\section{Conclusion and Summary}

Agricultural diversification remains one of the potent options to cope with issues related to poverty, youth unemployment, import dependent economy and underutilization of resources in the Sub-Saharan countries. However, the achievement of susutainable agricultural diversification is anchored on a sound economy and political environments among others. Hence, the identification of these macroeconomic variables became imperative in achieving the much anticipated susutainable agricultural diversification in the region.

On this premised, the study investigated the influenced of macroeconomic fundamentals on agricultural diversification in Nigeria from 1960 to 2014. The study used series of statistical and time series econometric techniques to investigate the relationship. The order of integration of data was ascertained using the Augmented Dickey-Fuller-GLS unit root test. The result indicated that series used in the analysis were integrated of order one. Following this, Engle Granger two-step method and Johansen's test were conducted on the specified variables to test for the presence of cointegration among series. The result of both test rejected the null hypothesis of no cointegration between agricultural diversification index and macroeconomic variables in Nigeria. The short run models were generated for the co-integrated series. The error correction term was appropriately signed and statistically significant at conventional probability levels indicating the possibility of ODI and HDI as well as EDI to converge to equilibrium in the long run, with intermediate adjustments captured by the differenced terms. These results implied that, the specified macroeconomic variables in the Nigeria's economy do interact in each period to re-establish the long-run equilibrium in agricultural diversification indices resulting from the short-run disturbances. The empirical 
result from the estimation of the long-run co-integration equation of agricultural diversification using HDI, ODI and EDI revealed the following macroeconomic variables as significant positive long run drivers of agricultural diversification in Nigeria; inflation rate, credit to agricultural sector, industrial growth, external reserves, per Capita GDP, unemployment rate and electricity consumption: whereas the long run negative drivers include, crude oil prices, commercial Bank lending rate, foreign direct investment in agriculture and non-oil imports.

The short run model provided evidence of positive significant influence of inflation, external reserves and non-oil import on agricultural diversification in Nigeria. Energy consumption and industrial production had negative effect in the short run on agricultural diversification. Also, a ten-year out sample forecast of agricultural diversification (HDI, ODI and EDI) revealed progressive growth in these indices till 2015. Variation in the diversification indices were further investigated by using impulse response function and variance decomposition analysis. The result was consistent with the earlier reported results.

Based on the finding of this study, it is recommended that, the federal government of Nigeria should provide suitable economic and political environments to achieve stability in inflation rate, external reserves, industrial production, electricity consumption and agricultural credit institution if a sustainable agricultural diversification is to be achieved in the long run. Also, such environments should be void of excessive intervention or protection as well as inflationary tendencies. In addition, as a way to develop other sectors of the economy and achieved sustainable agricultural diversification, import policies should be designed in line with the liberalization policy framework in the country.

\section{Acknowledgement}

We are grateful to our senior colleagues, who proof read the original manuscript and provided useful criticisms and recommendations that help shape this work. We also thank Mrs. Veronica Sunday Brownson for her several assistance especially; her ingenuity in assembling data used in this study.

\section{Funding Information}

Author contributed fund to finance this research work.

\section{Author's Contributions}

Sunday B. Akpan: The designed the research, develops methods of analysis and interpret the result of analysis.

Samuel J. Udoka: Reviewed relavant literature and proof read the original maniscript.
Inimfon V. Patrick: Took charge of data collection and arrangement. She also proof read the original manscript.

\section{Ethics}

This article is original and has not been previously published in any form. All citations are appropriately referenced. All authors have read, approved and confirmed that the article is void of unethical practices.

\section{References}

Brooks, C., 2008. Introductory Econometrics for Finance. 1st Edn., Cambridge University Press, Cambridge New York, ISBN-10: 052169468X, pp: 648.

CBN, 2005. Statistical Bulletin. Central Bank of Nigeria. CBN, 2015. Central Bank of Nigeria.

Dickey, D.A. and W.A. Fuller, 1981. Distribution of the estimators for autoregressive time series with a unit root. Econometrica, 49: 1057-1072.

Elliott, G., T.J. Rothenberg and J.H. Stock, 1996. Efficient tests for an autoregressive unit root. Econometrica, 64: 813-836. DOI: 10.2307/2171846

Fahim, A.M., 1998. Export diversification and growth: an empirical investigation. Applied Econ. Lett., 7: 559-562. DOI: 10.1080/13504850050059005

Feenstra, R., T. Yang and G. Hamilton, 1999. Business groups and product variety in trade: Evidence from South Korea, Taiwan and Japan. J. Int. Econom., 48: 71-100. DOI: 10.1016/S0022-1996(98)00024-5

Gujarati, D., 2003. Basic Econometrics, 4th Edn., McGraw Hill Company, New York.

Imbs, J. and W. Romain, 2003. Stages of diversification. Am. Econom. Rev., 93: 63-86. DOI: $10.1257 / 000282803321455160$

Johansen, S. and K. Juselius, 1990. Maximum likelihood estimation and inference on cointegration-with applications to the demand for money. Oxford Bull. Econom. Statis., 52: 169-210. DOI: 10.1111/j.1468-0084.1990.mp52002003.x

Johansen, S., 1988. Statistical analysis of cointegration vectors. J. Eco. Dynamics Control, 12: 231-254. DOI: 10.1016/0165-1889(88)90041-3

Laurenceson, J. and J.C. Chai, 2003. Financial reform and economic development in China. 1st Edn., Edward Elgar Publishing, Cheltenham, U.K, ISBN-10: 1843767198, pp: 159.

MacKinnon, J.G., A.H. Alfred and M. Leo, 1999. Numerical distribution functions of likelihood ratio tests for cointegration. J. Applied Econ., 14: 563-577.

McLaughlin, G., 1930. Industrial diversification in American cities. Q. J. Econ., 44: 131-149. DOI: $10.2307 / 1882529$.

NPC, 2015. National Population Commission Website. 
Nwosu, A.C., 1992. Structural adjustment and Nigerian Agriculture. United State Department of Agricultural Economic Research Service. Agriculture and Trade Analysis Division, USA.

Odife, D.O., 2004. Diversifying the Nigerian economy for sustainable development. Proceedings of the Opening Dinner of the Manufacturers Summit under the theme "Mapping the future of the Manufacturing Industry in Nigeria", April 14-16, African Leadership Forum, Ota, Ogun State.

Ogun, O., 1987. Nigeria's trade policy during and after the oil boom: An appraisal. University of Ibadan.

Olaleye, S.O., F. Edun and S.B. Taiwo, 2013. Export diversification and economic growth in Nigeria: An empirical test of relationship using a granger casualty test. J. Emerging Trends Econom. Manage. Sci., 5: 70-79.

Papageorgiou, C. and S. Nikolas, 2013. Economic diversification in low-income countries: Stylized facts IMF note.

Petit, M. and S. Barghouti, 1992. Diversification: Challenges and Opportunities. In: Trends in Agricultural Diversification: Regional Perspectives, Barghouti, S., L. Garbus and D. Umali (Eds.), World Bank, Washington D.C., ISBN-10: 0821321919.
Piñeres, S.A.G. and M.J. Ferrantino, 1997. Export diversification and structural dynamics in the growth process: The case of Chile. J. Dev. Eco., 52: 375-391. DOI: 10.1016/S0304-3878(96)00446-4

Rodriguez-Clare, A., 2005. Microeconomic interventions after the Washington Consensus (Working Paper No. 544). Washington, D.C., Inter-American Development Bank.

Shiyani, R.L. and H.R. Pandya, 1998. Diversification of agriculture in Gujarat: A spatio-temporal analysis. Indian J. Agric. Econom., 53: 627-639.

Tress, R.C., 1938. Unemployment and the diversification of industry. Manchester School, 9: 140-152. DOI: $10.1111 / \mathrm{j} .1467-9957.1938 . t b 01420 . \mathrm{x}$

Udoh, E. and A.U. Elias, 2011. Ten years of industrial policies under democratic governance in Nigeria: New Wine in Old Bottle. Eur. J. Soc. Sci., 20: 248-258. 